\title{
Growth Rates of a Cheatgrass Community and Some Associated Factors
}

\author{
D.W. URESK, J.F. CLINE, AND W.H. RICKARD
}

\begin{abstract}
Abiotic and biotic factors were found to be related to growth rates of a cheatgrass sward using stepwise regression analyses. Soil temperature and plant tissue nitrogen showed a strong relation with growth rates from initiation of growth to peak production. After peak production, soil temperature was related to declining growth rates. Water stored in the soil profile had a weak relationship with growth rates and plant growth was completed before soil water became limiting. Equations were developed using soil temperature, nitrogen content of plant tissues, and live herbage production to estimate future production of cheatgrass.
\end{abstract}

Cheatgrass (Bromus tectorum) is common throughout the rangelands of southcentral Washington and utilized by cattle in late winter and early spring. However, production varies from year to year, depending upon weather conditions between October and June. The dynamics of cheatgrass growth as related to abiotic and biotic factors is an important aspect of short-term management of arid rangelands in the Pacific Northwest.

The relationship between precipitation and peak standing crop of range forage plants has been investigated by Smoliak (1956), Sneva and Hyder (1962), Currie and Peterson (1966), Rauzi (1964), Albertson (1966), Hulett and Tomanek (1969), and Shiflet and Dietz (1974). Dahl (1963) related total yield of herbage with precipitation of the previous 2 years, evapotranspiration, and predicted yields from soil moisture. Cable (1975) found that perennial grass production in Arizona was primarily dependent upon summer rainfall. Uresk, et al. (1975) related the amount of live herbage production, leaf moisture, and air temperatures to rates of growth rather than to peak standing crop for blue grama grass.

This paper examines soil water, soil temperature, and mineral content of tissues as factors showing a relationship or causative effect on the growth of cheatgrass in south-central Washington over a 5-year period, 1971-1975.

\section{Study Area and Methods}

The study area is an abandoned agricultural field located on the Arid Lands Ecology (ALE) Reserve on the Department of Energy's Hanford Reservation (Cline and Rickard 1973; Rickard et al. 1976). The field supports a uniform sward of cheatgrass mixed with some minor species such as tansy mustard (Descurainia pinnata) and tumble mustard (Sisymbrium altissimum). Prior to agricultural practices, the

Authors are research biologist, U.S. Forest Service. Forestry Research Laboratory, South Dakota School of Mines and Tech. Rapid City, South Dakota 57701; and senior rescarch technologist and senior research scientist at Battelle, Pacific Northwest Laboratories, Richland. Washington 99352.

This work was conducted by Battelle-Northwest Laboratories for the U.S. Department of Energy under contract E(45-1)-18.30. Thanks are extended to V. Charles, H. Sweeney,

L. Rendall, M. Combs, and F. Nelson for their technical assistance.

Manuscript received April 17, 1978. plant community was representative of the Artemisia tridentata/Agropyron spicatum association (Daubenmire 1970). The soil is silt-loam with very few stones in the upper metcr of its profile. The climate is semiarid, with an average annual precipitation of $17 \mathrm{~cm}$ from October to May. There has been little or no grazing by livestock since the field was abandoned in 1943.

Two sites, each 0.1 ha in size were established near the center of the field. Herbage was harvested hy hand from ten randomly located $20 \times$ $50 \mathrm{~cm}\left(0.1 \mathrm{~m}^{2}\right)$ quadrats in each site. Sampling was conducted at 3 -week intervals throughout the spring growing season and once during the fall. Live herbage was hand separated from the dead material by species. The herbage was oven dried for 48 hours at $60^{\circ} \mathrm{C}$, weighed, and analyzed for total nitrogen, phosphorus, and potassium (U.S. Testing Company).

Percentage soil water (dry basis) was determined gravimetrically in soil samples collected at 1 -dm increments to a depth of $8 \mathrm{dm}$ using a barrel-type auger. Percent moisture was multiplied by bulk density to obtain soil water by volume. Soil temperature was measured by a recording thermograph with temperature sensing elements buried at 4 $\mathrm{dm}$.

Statistical analyses for stepwise regression followed Draper and Smith (1968). Herbage data were combined over 3 years (1971, 1972, and 1973) for these analyses, using site means by harvest dates. Regression equations related daily changes in amounts of herbage; factors were herbage weight (WT), plant nitrogen $(\mathrm{N})$, phosphorus $(\mathrm{P})$, potassium $(\mathrm{K})$, soil temperature $(\mathrm{T})$ at $4 \mathrm{dm}$ depth, and soil water (W) at $1-\mathrm{dm}$ increments to $8 \mathrm{dm}$ in depth. These data were separated into two periods of growth for analyses. First, regression equations were developed from the beginning of growth to peak biomass of cheatgrass and this interval is referred to as the accelerated growth period. Secondly, regression equations were determined from peak biomass to the end of growth, which is referred to as the senescent period.

The regression equations developed may be used to estimate future daily change in herbage weight of cheatgrass up to a maximum of three weeks. These equations were developed from the first three years of data and then tested on two independent years of data collected for 1974 and 1975. Only those independent variables that contributed significantly to the variation in the dependent variable (daily change in biomass) are presented in this study.

\section{Results}

The average maximum biomass production of cheatgrass during the 5 years (1971-1975) was $224 \mathrm{~g} / \mathrm{m}^{2}$ (Table 1). The extreme low, $132 \mathrm{~g} / \mathrm{m}^{2}$, occurred in 1972 while the peak high occurred in 1974 with $328 \mathrm{~g} / \mathrm{m}^{2}$. The average rate of growth to peak biomass production was $2.9 \mathrm{~g} / \mathrm{m}^{2} /$ day for three years (1971-1973). After peak production, the live tissues decreased at an average value of $3.8 \mathrm{~g} / \mathrm{m}^{2} /$ day. Precipitation during November to April was lowest for the 1973 season with $11 \mathrm{~cm}$ of water; highest November to April precipitation occurred during the 1974 growing season with $26 \mathrm{~cm}$. 
Table 1. Seasonal biomass values of cheatgrass $\left(\mathrm{g} / \mathrm{m}^{2}\right)$, nitrogen content of tissues and soil temperature during the years 1971-1975.

\begin{tabular}{|c|c|c|c|}
\hline $\begin{array}{l}\text { Year } \\
\text { Mo-Da }\end{array}$ & $\begin{array}{l}\text { Herbage } \\
X \pm S E^{1}\end{array}$ & $\begin{array}{c}\text { Nitrogen } \\
\%\end{array}$ & $\begin{array}{c}\text { Soil temp }\left(C^{\circ}\right) \\
4 \mathrm{dm}\end{array}$ \\
\hline \multicolumn{4}{|l|}{1971} \\
\hline $3-08$ & $35.5 \pm 2.9$ & 1.95 & 3.9 \\
\hline 4-01 & $59.6 \pm 5.7$ & 1.56 & 8.5 \\
\hline 4-19 & $126.9 \pm 7.8$ & 1.30 & 11.2 \\
\hline $5-07$ & $198.4 \pm 11.7$ & 0.95 & 15.4 \\
\hline $5-28$ & $124.9 \pm 11.1$ & 0.57 & 21.0 \\
\hline $11-10^{2}$ & $47.5 \pm 5.9$ & 2.08 & 7.5 \\
\hline \multicolumn{4}{|l|}{1972} \\
\hline $3-14$ & $56.3 \pm 4.1$ & 2.31 & 9.8 \\
\hline 4-03 & $76.4 \pm 2.6$ & 1.48 & 10.3 \\
\hline $4-13$ & $131.7 \pm 6.6$ & 1.11 & 10.5 \\
\hline $4-25$ & $126.2 \pm 5.5$ & 1.00 & 13.2 \\
\hline $5-15$ & $112.1 \pm 20.2$ & 1.03 & 19.0 \\
\hline \multicolumn{4}{|l|}{1973} \\
\hline $3-06$ & $32.0 \pm 3.2$ & 2.25 & 7.8 \\
\hline $3-26$ & $36.4 \pm 2.3$ & 2.10 & 9.5 \\
\hline $4-06$ & $70.4 \pm .5 .2$ & 2.14 & 12.8 \\
\hline $4-23$ & $115.1 \pm 11.3$ & 1.83 & 15.5 \\
\hline $5-07$ & $165.8 \pm 11.2$ & 1.18 & 17.3 \\
\hline $5-18$ & $62.2 \pm 6.8$ & 1.70 & 16.5 \\
\hline \multicolumn{4}{|l|}{1974} \\
\hline $3-13$ & $78.0 \pm 4.7$ & 2.04 & 7.0 \\
\hline $4-11$ & $143.6 \pm 7.5$ & 1.23 & 8.5 \\
\hline $4-28$ & $253.1 \pm 14.1$ & 0.64 & 13.0 \\
\hline $5-22$ & $328.0 \pm 16.1$ & 0.40 & 17.2 \\
\hline \multicolumn{4}{|l|}{1975} \\
\hline $3-20$ & $60.0 \pm 6.8$ & 2.60 & 4.8 \\
\hline $4-28$ & $193.0 \pm 7.6$ & 1.13 & 10.0 \\
\hline $5-13$ & $294.5 \pm 18.6$ & 0.54 & 14.1 \\
\hline $6-06$ & $221.4 \pm 15.4$ & 0.40 & 21.0 \\
\hline
\end{tabular}

Mean \pm standard error.

Regrowth of cheatgrass.

Nitrogen content in live tissues ranged from $0.40 \%$ to a high of $2.60 \%$ (Table 1). Nitrogen content was highest early in the growing season with values exceeding $2 \%$. Peak yield of plant nitrogen ranged from 1.5 to $2.2 \mathrm{~g} / \mathrm{m}^{2}$ during the 5 years. Average peak yield of nitrogen in cheatgrass was $1.9 \pm 0.1 \mathrm{~g} / \mathrm{m}^{2}$ $( \pm \mathrm{SE}$ ). Soil temperatures at a 4-dm depth ranged from a low of $3.9^{\circ}$ to $21.0^{\circ} \mathrm{C}$ during the harvest periods from 1971 to 1975 (Table 1).

In the cheatgrass community, $50 \%$ of the variation in changes during the spring period of accelerated growth was accounted for by the amount of live herbage present (WT) (Equation 1, Table 2), while the amount of live herbage accounted for $48 \%$ of the variation during the senescent period (Equation 4). These equations may be used to estimate growth rates when soil temperatures or plant nitrogen are not available.

Soil temperature (T) accounted for $44 \%$ of the variation in daily growth (Equation 2, Table 2), and soil temperature and nitrogen $(\mathrm{N})$ accounted for $77 \%$ of the variation (Equation 3 ). During the late fall of each year after soil water is replenished, soil temperature appears to influence or show a relationship with plant growth. Soil temperature may be the most reliable single factor to estimate growth rate until $11^{\circ} \mathrm{C}$ is reached. At temperatures above $11^{\circ} \mathrm{C}$, nitrogen begins to influence or show a relationship with plant growth. Then Equation 3 is best used to estimate growth rates until a temperature of $15^{\circ} \mathrm{C}$ is obtained or approximately $0.5 \%$ nitrogen is present in the
Table 2. Regression equations showing the influence of biotic and abiotic factors on daily growth rates $(\hat{\mathbf{Y}})$ of live cheatgrass from initiation of growth to peak herbage production (accelerated growth period) and post-peak herbage production (senescent period) to cessation.

Equation $R^{2}$

$R^{2}$

$\begin{array}{cc}\text { Accelerated Growth Period } & \\ \hat{\mathrm{Y}}=0.224+0.038(0.0096)^{1} \mathrm{WT}^{2} & 0.50^{* *} \\ \hat{\mathrm{Y}}=-0.971+0.393(0.114) \mathrm{T} & 0.44^{* *} \\ \hat{\mathrm{Y}}=5.61+0.345(0.077) & 0.77^{* *} \\ \mathrm{~T}-3.211(0.726) \mathrm{N} & \\ \text { Senescent Period } & 0.48^{*} \\ \hat{\mathrm{Y}}=6.68-0.06(0.028) \mathrm{WT} & 0.66^{* *}\end{array}$

' (1) Standard error

$2 \mathrm{WT}=$ The amount of live herbage at a given time;

$\mathrm{T}=$ Soil temperature at $4 \mathrm{dm}$;

$\mathrm{N}=$ Nitrogen content.

Significant at $\alpha \leq 0.10$

*** Significant at $\alpha \leq 0.01$.

cheatgrass tissues. The decrease in live herbage was a function of soil temperature (Equation 5), which accounted for $66 \%$ of the variability. Soil temperature was the most highly correlated independent variable of all parameters associated with growth rates of cheatgrass during the senescent period. Soil water in the upper meter of soil profile did not contribute significantly to daily growth rates of cheatgrass biomass during both growth periods in the stepwise regression analyses.

Soil water as rclated to daily growth rates of cheatgrass showed differences by depth when comparing the accelerated growth and senescent periods (Table 3 ). Soil water showed a significant relationship with growth rates during the accelerated growth period to a depth of $9 \mathrm{dm}$. However, during the senescent period, late in the growing season, growth rates were significantly related with soil water only to a depth of $4 \mathrm{dm}$. Higher correlation coefficients $(r)$ are shown for the senescent period; however the lower soil depths are not significant which may be due to a smaller sample size. Cline et al. (1977) showed that, in years where adequate soil moisture is available, soil water is not fully exploited by cheatgrass at the lower depths below $4 \mathrm{dm}$. During 1971-1973, the growth of cheatgrass had terminated before deeply stored soil water was used. However, during the drier years when soil water did not penetrate below the $5 \mathrm{dm}$ soil profile, growth was limited primarily by soil water, rather than temperature and plant nitrogen.

The estimated values of biomass for the growing seasons of 1974 and 1975 were obtained from Equations 2, 3, and 5, which

Table 3. Correlation coefficients $(r)$ of soil water with growth rates of cheatgrass during the accelerated growth and senescent periods of herbage production at $1-\mathrm{dm}$ increments to a depth of $10 \mathrm{dm}$.

\begin{tabular}{lcc}
\hline \hline Soil depth $(\mathrm{dm})$ & $\begin{array}{c}\text { Accelerated } \\
\text { growth period }\end{array}$ & Senescent period \\
\hline $0-1$ & $-0.60^{*}$ & $0.86^{*}$ \\
$1-2$ & $-0.59^{*}$ & $0.85^{*}$ \\
$2-3$ & $-0.60^{*}$ & $0.77^{*}$ \\
$3-4$ & $-0.59^{*}$ & $0.75^{*}$ \\
$4-5$ & $-0.58^{*}$ & 0.73 \\
$5-6$ & $-0.57^{*}$ & 0.72 \\
$6-7$ & $-0.56^{*}$ & 0.74 \\
$7-8$ & $-0.55^{*}$ & 0.73 \\
$8-9$ & $-0.50^{*}$ & 0.72 \\
$9-10$ & -0.48 & 0.66 \\
\hline
\end{tabular}

Significant at $\alpha \leq 0.05$. 


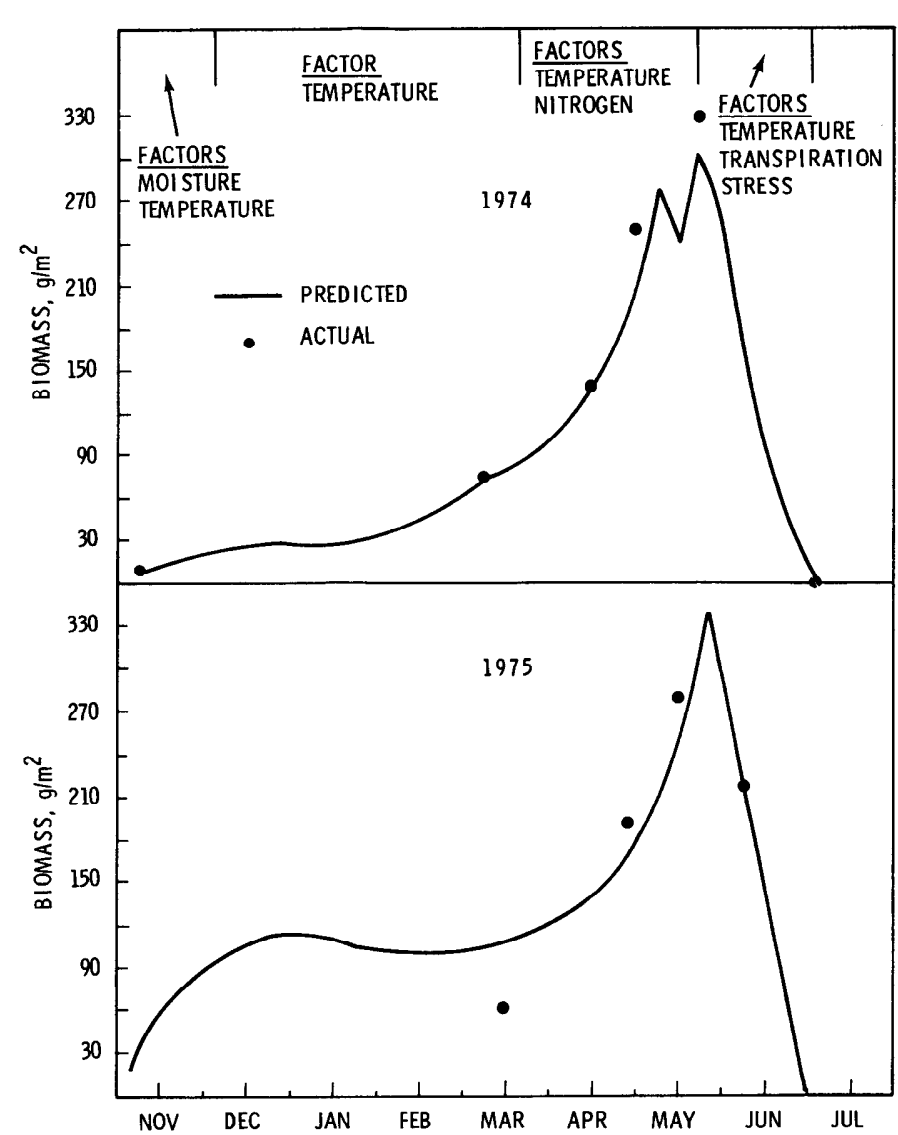

Fig. 1. Abiotic and biotic factors which were most influential in estimating the growth of cheatgrass are presented and a comparison of estimated versus actual biomass values during the 1974 and 1975 growing seasons.

were developed for years 1971-1973 (Table 2). Changes in herbage growth rates were predicted at future weekly intervals and these values were summed for each week to obtain total biomass. Reasonable agreement was shown between estimated and actual biomass values throughout the growing season for both years (Fig. 1).

\section{Discussion}

Temperature affects the qualitative and quantitative development of plants. The structural development and physiological processes of a plant may vary greatly with the temperature of the environment, depending on species. The annual growth of cheatgrass falls into three seasonal phases as related to soil temperatures-limited, relatively unaffected, and inhibited. The limited phase is defined as that period when temperature is not sufficient to allow optimum development of the plant. The relatively unaffected phase is that period where temperatures are favorable for optimum plant growth, while the inhibited phase is defined as that period when excessive temperatures retard or inhibit plant growth (Jarvis and Jarvis 1973). When soil temperatures were low i.e., $1.9-3.5^{\circ} \mathrm{C}$, cheatgrass growth was initiated (limited phase). The unaffected phase of growth occurred between $3.5^{\circ} \mathrm{C}$ and $15^{\circ} \mathrm{C}$. Above $15^{\circ} \mathrm{C}$, the growth rate decreased; growth ceased at approximately $27^{\circ} \mathrm{C}$ (inhibited phase).

Temperature is an important factor influencing germination of cheatgrass. New seeds have the highest germination success at air temperatures of $10^{\circ} \mathrm{C}$, seeds 4 weeks old $-15^{\circ} \mathrm{C}, 7$-week old seeds $-15^{\circ} \mathrm{C}$ to $20^{\circ} \mathrm{C}$, and 1-year-old seeds $-20^{\circ} \mathrm{C}$ (Hulbert 1955). Germination occurs in the fall in southcentral Washington, with some leaf growth prior to the onset of low winter temperatures.

The nitrogen content of cheatgrass tissues also appears to influence production. When nitrogen content ranges between $0.5 \%$ to $2 \%$ or even higher, optimal growing conditions prevail. Growth of cheatgrass may become arrestcd when tissue nitrogen is less than $0.5 \%$. Cline and Rickard (1973) showed that cheatgrass production was low when plant tissue nitrogen was below $0.7 \%$.

During late fall, winter, and early spring when soil moisture is available, low soil temperature is the factor regulating the growth of cheatgrass. When adequate soil moisture is available for growth, both temperature and nitrogen influence the growth rates of cheatgrass. Apparently at this site all growth was completed before soil water became a limiting factor, with soil temperature causing growth to stop.

The estimated biomass production for 1974 and 1975 compares favorably with actual harvest data (Fig. 1). Soil temperature showed a strong relationship with growth rates of cheatgrass throughout the growing season, while plant nitrogen displayed a strong relationship when cheatgrass was vigorously growing. Soil water did not demonstrate this strong relationship with growth. However, during the fall, adequate moisture must be available to initiate growth and seed germination.

\section{Literature Cited}

Albertson, F.W. 1966. Ecological studies of blue grama grass (Bouteloua gracilis). Fort Hays Studies. Sci. Ser. No. 5. 37 p.

Cable, D.R. 1975. Influence of precipitation on perennial grass production in the semi-desert southwest. Ecology 56:981-986.

Cline, J.F., and W.H. Rickard. 1973. Herbage yields in relation to soil water and assimilated nitrogen. J. Range Manage. 26:296-298.

Cline, J.F., D.W. Uresk, and W.H. Rickard. 1977. Comparison of soil water used by a sagebrush-bunchgrass and a cheatgrass community. J. Range Manage. 30:199-201.

Currie, P.O., and G. Peterson. 1966. Using growing-season precipitation to predict crested wheatgrass yields. J. Range Manage. 19:284-288.

Dahl, B.E. 1963. Soil moisture as a predictive index to forage yield for the sandhills range type. J. Range Manage. 18:94-96.

Daubenmire, R. 1970. Steppe vegetation of Washington. Wash. Agr. Exp. Sta. Tech. Bull-62 $131 \mathrm{p}$.

Draper, N.R., and H. Smith. 1968. Applied Regression Analysis. John Wiley and Sons, Inc. New York. 407 p.

Hulbert, L.C. 1955. Ecological studies of Bromus tectorum and annual brome grasses. Ecol. Monogr. 25:181-213.

Hulett, G.K., and G.W. Tomanek. 1969. Forage production on a clay upland site in westem Kansas. J. Range Manage. 22:270-276.

Jarvis, M.S., and P.G. Jarvis. 1973. Stalfet's Plants Ecology, Plants, the soil and man. [Transl. from Swedish] John Wiley and Sons, Inc. New York. 592 'p.

Rauzi, R. 1964. Late-spring herbage production on shortgrass rangeland. J. Range Manage. 17:210-212.

Rickard, W.H., D.W. Uresk, and J.F. Cline. 1976. Productivity response to precipitation by native and alien plant communities, p. 1-7. In: Proceedings of the Symposium on Terrestrial and Aquatic Ecological Studies of the Northwest. Eastern Washington State College. Cheney. Wash.

Shiflet, T.N., and H.E. Dietz. 1974. Relationship between precipitation and annual rangeland herbage production in southeastern Kansas. J. Range Manage. 27:272-276.

Smoliak, S. 1956. Influence of climatic conditions of forage production of shortgrass rangeland. J. Range Manage. 9:89-91.

Sneva, F.A. and D.N. Hyder. 1962. Estimating herbage production on semiarid ranges in the Intermountain Region. J. Range Manage. 15:88-93.

Uresk, D.W., P.L. Sims, and D.A. Jameson. 1975. Dynamics of blue grama within a shortgrass ecosystem. J. Range Manage. 28:205-208.

U.S. Testing Company. n.d. Quality control manual, soil and plant analytical procedures. Richland, Washington. 